\title{
Decentralization in Secondary Education System: Issues and Challenges
}

\begin{abstract}
H. Syafa'at Anugrah Pradana
The State Institute for Islamic Studies of Parepare, South Sulawesi, Indonesia

Abstract

In Indonesia, classification of decentralization is divided into 3 (three) includes formal, material and real decentralizations. Decentralization is elaborated from several theories that exist to assess concurrent governmental or governmental affairs as domain of local government. For affairs in the field of education, especially in the management of secondary education, the form of decentralization is territorial decentralization. While, functional and cultural decentralization are not included in the form of decentralization as applied in Indonesia. The results show that the form of decentralization of education management in Indonesia uses territorial decentralization, considers the geographical conditions of Indonesia so that it is a consideration that Indonesia uses territorial decentralization in conducting concurrent government affairs, one of which is secondary education. Indonesia should not only use a form of territorial decentralization in government affairs, but also must use a form of cultural decentralization because Indonesia is a country that with diverse culture. Therefore, it needs to be preserved through a form of cultural decentralization.
\end{abstract}

Keywords: Decentralization; Education System; Classification; Local Government

DOI: $10.7176 / \mathrm{JAAS} / 58-08$

Publication date:September $30^{\text {th }} 2019$

\section{Introduction}

In this world, only those nations have survived and competed with challenges which have a quality and sound education system. ${ }^{1}$ There are many reasons for education stakeholders to support this change that progresses to decentralization. Among these reasons, there are local authorities' being willing to get responsibility about education. In general, decentralization is classified under four different types named political, administrative, fiscal and market decentralization. ${ }^{2}$ While political decentralization deals with giving the power to local governments for decision making processes, in administrative decentralization the planning and management responsibilities are given to local units.

Van Der Pot views that territorial decentralization manifest in the form of bodies based on the region (gebiedscorporaties), while functional decentralization manifest in the form of bodies based on specific goals (doelcorporaties). ${ }^{3}$ Territorial decentralization is autonomy and assistance tasks. Autonomy implies independence to manage and administer their affairs (its household). While, assistance task is a task to help if needed to implement higher legislation (laws and government regulations).

The notion of territorial and functional decentralizations are not different from general notions (as expressed by Van Der Pot), whereas those interpreted as administrative decentralization or de-concentration (ambtelijke decentralisatie) occur when "the government delegates a part of its authority to the apparatus or government organ itself in the regions, namely government officials in the regions to be implemented.

Related with the relationship between decentralization and de-concentration, it is acknowledged by Soejito that there were two views. The first views that de-concentration as a form of decentralization. The second views deconcentration is just a softening of centralization towards decentralization. In other words, de-concentration is part of centralization, not decentralization. This second view can be seen in de Meij's opinion who said "In tegenstelling tot bij decentralisatie iser bij deconcentratie sprake van organen die ondergeschiekt zijn aan de hogere overhead". Amrah Muslimin distinguishes decentralization into political, functional and cultural decentralizations. ${ }^{4}$

\footnotetext{
${ }^{1}$ Cohen, D. K., \& Ball, D. L. (1990). Relations between policy and practice: A commentary. Educational Evaluation and Policy Analysis, 12, 331-338.

${ }^{2}$ Balkar, B., \& Kasurka, M. G. (2015). Decentralization as an Educational Planning Strategy in Turkish Education System. International Journal of Education, 7(2), 415-436.

${ }^{3}$ Manan, B. (1994). Hubungan Antara Pusat dan Daerah Menurut UUD 1945. Jakarta: Pustaka Sinar Harapan, p. 25

${ }^{4}$ Muslimin. A. (1978). Aspek-Aspek Hukum Otonomi Daerah. Bandung: Alumni. p. 15
} 
Is it appropriate to include "cultural decentralization" as a form of decentralization? Decentralization is a form of organizational structure of the State consisting of central government units and lower government units that are established either by territorial or certain government functions. The two lower forms of government unit carry out part of the government affairs of the State. As well as, the granting or recognition of minority rights to regulate and administer affairs of religion and education in their own circles; it is more a manifestation of the recognition and protection of human rights than as part of the organizational structure of the State. Likewise, the granting of rights to embassies to organizes their own education. The embassy is not part of the organizational structure of the State where the embassy is located. The embassy is part of the organizational structure of the State as represented.

Apart from the similarities and differences between the Indonesian authors as mentioned above, the fact indicates that the notion of decentralization they propose is broader than the notion of decentralization as argued by Van Der Pot who only knows two forms of decentralization (territorial and functional). But the differences are still in one framework, namely decentralization as the principle of implementing a unitary State government. These notions are very different from the notion of decentralization as argued by Hans Kelsen.

Based on a static conception, decentralization does not reflect the authority of regions to make their own rules to regulate their households. Because the rules determined are valid for certain parts of the region, it can be determined by the central government and not local government. Thus, in decentralization as argued by Van Der Pot, in addition to the static concept, Kelsen also reviewed decentralization from the point of dynamic conception. From the concept of decentralization mentioned above, the author interests to construct a classification of decentralization, especially towards the management of secondary education which is part of the decentralized governmental affairs.

\section{Classification of Decentralization in Indonesia}

Legal education objectives in Indonesia have experienced a number of changes over time. ${ }^{5}$ For this reason, the national education system should be able to ensure equal distribution of educational opportunities, quality improvement and the relevance and efficiency of education management to face challenges in line with the changing demands of local, national, and global life so that education reforms are planned, directed and sustainable. The importance of education in addition to the intellectual life of the nation, to promote human rights in Indonesia, education is also an important tool to advance knowledge, and the dignity and dignity of the Indonesian nation. ${ }^{6}$

Decentralization uses the pattern of regional household systems in expressing the classification of decentralization, especially in Indonesia. The regional household system is the order concerned with ways to divide the authority, duties and responsibilities of regulating and managing central and local government affairs. One manifestation of the division namely regions will have a number of government affairs either on the basis of surrender or recognition or which are left as regional household affairs.

The division as mentioned above can be indicated several regional household systems, namely formal, material and real household systems. The first, in the formal household system, the division of authority, duties and responsibilities between the center and the local to regulate and manage certain government affairs is not specified in detail.

The formal household system comes from the principle that there is no difference in nature between the affairs held by the center and those held by the local. Whatever can be held by the center can basically also be held by the local. The division of authority, duties and responsibilities to regulate and manage a government affair is solely based on the belief that a government affair will be better and more successful if it is managed and regulated by a particular government unit, and vice versa. Consideration of efficiency (and effectiveness) is a focal point for determining the division of duties, authority and responsibilities. ${ }^{7}$

Theoretically, the formal household system gives the widest possible power to the regions to regulate and manage government affairs and make these affairs as regional household affairs. ${ }^{8}$ In fact, the formal household system is not always a driving-force for regions to manage and regulate government affairs. There are several difficulties in enhancing the use of formal household systems, as follows:

a. The level of efficiency and effectiveness of formal household systems depends on regional creativity

\footnotetext{
${ }^{5}$ Juwana, H. (2006). Legal education reform in Indonesia. Asian Journal of Comparative Law, 1(1), 1932-0205.

${ }^{6}$ Limpo, I.Y., Bachri, S., Ilmar, A., and Patittingi, F. (2018), Potret of Basic Education in Indonesia (A Legal Political Study), Journal of Law, Policy and Globalization, Vol 69.

${ }^{7}$ Koesoemahatmadja. (1979). Pengantar Kearah Sistem Pemerintahan Daerah Di Indonesia. Binacipta: Bandung. p.18

${ }^{8} \mathrm{Ibid}, \mathrm{p} .26$
} 
and activities.

b. Regions must be able to see affairs which according to their considerations are important for the region and reasonable and appropriately regulated and managed by the region. For regions that are less able to take advantage of opportunities, in reality much will depend on the center or higher level regions. Regions will always await "guidance" regarding government affairs that should be regulated and managed.

c. Another obstacle is regional finance. ${ }^{9}$ Although the regions have wide opportunities to develop regional household affairs, this cannot be done without adequate financial resources.

d. No less important are technical obstacles. The regions cannot easily find out affairs that have not yet been held by the central government or higher level regional government. ${ }^{10}$

Reviewed from the perspective of the relationship between the center and the local government, at first glance the formal household system provides a strong opportunity for decentralization, strong autonomy arrangements. In fact, it is not the case, even the opposite is possible. The formal household system is a good tool to support the centralization. The uncertainty of regional household affairs, there is no tradition of autonomy, the lack of regional initiative will manifest regions that are always waiting and depend on the center. Even more, if regional finance is unable to sustains its activities and also depends on financial assistance from the center.

The second, doubts and uncertainties in the formal household system can be overcome by material household systems. In a material household system, there is a division of authority, duties and responsibilities in detail between the center and the local. Government affairs which are included in regional household affairs are determined surely. Material household systems come from the idea that there are indeed fundamental differences between central and local government affairs. Regions are deemed to have a separate scope of government affairs that are materially different from government affairs that are regulated and administered by the center.

Hence, if a State only has two organizational units (central and only one autonomous regional unit) it certainly cannot be called the teachings of three spheres. The essence does not lie in two or three organizational units of government, but rather that government affairs can be fundamentally selected from one another. Selection is not only possible, but it is indeed expected “...dat een volstrektescheiding tussen de huishoudingen van rijk, provincies en gemeenten mogelijk en wensenlijk is". ${ }^{11}$

As facts above, it is very difficult to determine in detail the affairs of each government unit. Furthermore, the material household system does not provide an opportunity to quickly adjust a government affair to the changes that occur. A government affair which was originally considered as something local, because development it can turn into a national-style affair, so it needs to be regulated and managed nationally. For example, waste issues. As result of the development of industry, the notion of waste has changed from the notion that is known traditionally. At this time, in terms of waste including industrial, nuclear wastes and so on. If it is related to environmental sustainability, wider public interests will be involved. Based on the analysis, it can be concluded that the material household system cannot be used as an objective benchmark for creating a harmonious relationship between the center and local government.

The third, the household system is also commonly called real autonomy. It is called "real", because the contents of regional households are based on real conditions and factors. Tresna said this system took a middle ground. Certainly, what meant as middle ground are formal and material household systems. The problem is: which of the two systems is dominant? Are the two operating in a balanced way?

Noting what Tresna argued, it seemed that the methods contained in the formal household system were the principle that took precedence over the methods according to the material household system. If this conclusion is true, why so and what is the purpose? To get answers to these questions, we must investigate and think about the thoughts that underlie the real household system.

As mentioned earlier, the authority as common formulated in the formal household system provides the basis for realizing the principles of freedom and independence in the household. On the other hand, it has also been mentioned about objections to the material household system. Material household systems will stimulate regional dissatisfaction and relation spanning between the center and local. Thus, formal household systems contain stronger foundations for realizing household principles and goals than material household systems.

\footnotetext{
${ }^{9}$ Muslimin, A. Op.Cit. p. 135

${ }^{10}$ The Liang Gie, (1968). Pertumbuhan Pemerintahan Daerah Di Negara Republik Indonesia, $3^{\text {rd }}$ edition. Jakarta: Gunung Agung. p.62

${ }^{11}$ Theo A.J. Toonen. (1987). Denken Over Binnenlands Bestuur Theorieen van de gedecentraliseerde eenheidstaat bestuurkundig beschouwd. Vuga, s'gravenhage. p.70
} 
In this context, it can be understood if the real household system lays its principles in the formal household system. Only with a formal household system that is accompanied by elements of a material household system, household goals, especially autonomy can be realized naturally. What the function of material households in real households? With a number of governmental affairs delegated, from the beginning the region has certainty about the regional household affairs. Certainly, it can also be questioned: What is not possible for the opposite to be the material household system which is the principle of a real household system. The formal household aspect is precisely as a complete complement.

Material household aspects in the real household system arises some criticism. The affairs that were given at the time of the formation of the region, causes the household system was not consistent. Certainly, there already a provision stating that regions are allowed to regulate and manage all government affairs as long as they are not yet regulated and administered by the center (hierarchische taakafbakening)? Why should there be another base? In this association, Boedisoesatyo in The Liang Gie states ${ }^{12}$ "if it is planned as such, what is the need for "establishing certain functions as "just a beginning"? Is not the base of the beginning according to the system has appeared itself, as things that have not been regulated by the agency that is more superior? According to this system, there is no beginning; the affair of the beginning of the division divides itself! (het problem lost zich zelf $o p$ ). If it requires assignment of affairs as a base of the beginning, why not need assignment of affairs for the next)." According to Boedisoesatyo, the methods for determining household affairs cause a real household system without a system. ${ }^{13}$

Main objection of Boedisoesatyo seem lies in the provisions governing the base affairs. He assumed that the basic affairs would be automatically available, namely all affairs that had not been regulated and managed by the higher level government units. This rationale will result in no difference between the real household system and the formal household system. The aspect of a material household system in the form of a base affair in addition to the aspect of a formal household system actually becomes one of the characteristics that distinguish real household systems from those of other household systems.

As argued by Tresna, something can be called a system if it has specific signs that distinguish it from existing systems. What the real households have those specific characteristics? It is true that real households contain characteristics of formal household systems and characteristics of material households. Although, real households show characteristics that distinguish it from formal household systems and material household systems, namely: the firstly, the presence of a base affair set at the time of the formation of an autonomous region, provides certainty regarding regional household affairs. It is not possible in formal household systems; the secondly, in addition to household affairs set "materially" from regions in real households, they can regulate and manage all government affairs which are considered important for the region as long as they are not regulated and managed by the central or upper-level regions; the thirdly, autonomy in real households is based on real factors of a region. This allows differences in the content and type of regional household affairs according to their individual circumstances.

Based on the characteristics above it is not exaggerating to say that real households do indeed reflect their own systems that are different from formal and material household systems. As a middle way, the real household system is expected to overcome the difficulties or weaknesses contained in the formal and material household system. Thus, a healthy and strong household system can be realized within a framework of harmonious relations between the center and the local/region.

\section{Form of Decentralization in Secondary Education Management in Indonesia}

Territorial decentralization is the transfer of power to regulate and manage their own households (autonomy), while its arrangement limits are regional. It resulted in autonomy in the regions that receive transfer. The first phase, the period of 1945-1948, as the beginning of independence, education policy was national. This happens because the State is still at the peak of its independence. Therefore, there is no political decentralization in the field of education, but the nationalization of education in Indonesia. In this phase, territorial government affairs in the field of secondary education are still not decentralized. The reason was because at that time, the Indonesian State was still struggling with the struggle for independence so that it had not been focused on the transfer of authority in the field of education. However, the division of regions has been stipulated in Article 18 of the 1945 Constitution which states "the division of Indonesian territory over large and small regions, with the form of government structure determined by law, by considering and observing the basis for deliberation in the State government system, and original rights in special region."

\footnotetext{
${ }^{12}$ The Liang Gie, Op.Cit, p. 58

${ }^{13} \mathrm{Ibid}$
} 
The second phase, the period of 1948-1957. In this phase there is also no division of government affairs between the central and regional local governments in the field of education. At that time it coincided with a change in the form of the State from a federation to a unitary that it affected the flexibility of the division of government affairs including government affairs in the field of education. The change in the form of the State from a federation to a unitary made the government not yet think about decentralizing authority in the field of education. What was thought by the State at the time was how to nationalize education, for the sake of the ideals of a Unitary of the Republic of Indonesia.

The third phase, the period of 1957-1965. At this time, the pattern of education management was still same as the second phase. This third phase as a phase for structuring region with the enactment of Act No. 1 of 1957 concerning the Principles of Regional Government amended Act No. 22 of 1948 and Act of NIT No. 44 of 1950. The structuring of the regions is the division of autonomy and special autonomy regions. Thus, although there are no specific regulations governing the distribution of educational affairs or in other words the decentralization of government affairs in the field of education, but the arrangement of this region has become a bright spot in order to economize education affairs in every region in Indonesia.

The fourth phase, the period of 1965-1974. In this phase, President Soekarno gave the concept of Pancawardhana education. Pancawardhana is a political document of Indonesian National Education as an effort to develop Indonesian National Education. The concept was recorded in UNESCO and through the Mission Head of UNESCO to Indonesia was translated into English into "The Five Principles of Education" which contained: ${ }^{14}$

a. Development of national and homeland love, moral, national/international/ religion;

b. Development of intelligence;

c. Development of emotional, artistic or sense and beauty of physical and spritual;

d. Development of crafts; and

e. Development of physical

These concepts arose as that period was a time with high nuances of nationalism and patriotism, therefore the Indonesian people were expected to always have a high spirit of nationalism. Also, the State directed the regions to unite in thought and action to complete the stages of the Indonesian revolution, at that time.

Pancawardhana is a program of moral, intelligence, emotional, skill and physical personal developments. This is in accordance with the ideals of the Political Manifestations of President Soekarno at that time. The manifestations of the system in question are Pancadanna, specialization of Islam, Catholic, Protestant, Buddhist, Balinese Hinduism, and Panca Cinta. The concerned Panca Cinta are love to learn, love to work, love to people, love to motherland, and love to ideology. In essence, in the fourth phase there was also no political decentralization in the field of education especially secondary education, but the focus was on strengthening religious values as an absolute element in the framework of the nation and character building.

The fifth phase, the period of 1974-1999. This phase is the beginning of the decentralization of education in Indonesia. Act No. 5 of 1974 concerning Principles of Government in Regions provides the interpretation that the unification of an autonomous region is the implementation of the principle of decentralization and the administrative region as the implementation of the principle of de-concentration. Even so with the enactment of Act No. 1989 concerning the National Education System which has combined the entire integrated education system of all educational units and activities in order to realize the objectives of national education.

At this time, decentralization of government affairs in the field of education is evidenced by the regulation of clarity of direction in each education unit. The use of local languages as an intermediary language in the early stages of education and to the extent required in the delivery of certain knowledge and/or skills is a characteristic of territorial education in Indonesia.

The State provides policies for citizens aged 6 years to attend basic education, while citizens aged 7 years are required to attend basic education to graduate. In this phase, there is no political decentralization in the field of education because the responsibility for education is entirely in the hands of the relevant ministers. The focus of education policy in this phase lies in the uniformity of the language of instruction, namely Indonesian.

The sixth phase, the period of 1999-2004. This is an initial phase of political decentralization in the field of education. District/cities governments are given authority in terms of managing primary and secondary education. While, the provincial government is given authority to coordinate and supervise primary and secondary education. Thus, the realization of political decentralization in this phase was reflected in the division of authority over government affairs in the field of education including secondary education. Also, in this phase the decentralization of education de facto and de jure. Act No. 20 of 2003 concerning the National Education System

\footnotetext{
${ }^{14}$ Poerbakawatja. (1970). Pendidikan Dalam Alam Indonesia. Jakarta: Gunung Agung. p. 420
} 
has divided the authority, duties and functions of the division of education management in Indonesia. The territory of secondary education management can be seen from the division of authority between the provincial and district/cities governments. The provincial government has the authority to coordinate the administration of education, the development of education personnel, and the provision of cross-regency/cities education delivery facilities for primary and secondary education. While the regency or cities government manages basic and secondary education, as well as education units based on local excellence (Table 1).

Table 1. Affairs of Secondary Education in Indonesia

\begin{tabular}{cl}
\hline \multicolumn{1}{c}{ Government } & \multicolumn{1}{c}{ Responsibility } \\
\hline Provincial Government & $\begin{array}{l}\text { Coordination of education, personnel development, and } \\
\text { provision of educational facilities across districts/cities. }\end{array}$ \\
\hline Regency/City Government & $\begin{array}{l}\text { Manage basic and secondary education, as well as } \\
\text { education units based on local excellence. }\end{array}$ \\
\hline
\end{tabular}
Source: Primary data, 2019 (edited).

The seventh phase, the period of 2004-2014. This phase is a continuation of the sixth phase related to the decentralization of educational territories. Adding to this phase is the scope of oversight for the management and administration of education. The provincial government has the authority to coordinate and supervise the Early Education, basic and secondary education. While the district/city government has the authority to supervise the management and administration of the Early Education, basic, secondary and non-formal education.

The eighth phase, the period of 2014 until now. In this phase, there were significant changes related to the territory of education decentralization in Indonesia. In Act No. 23 of 2014 concerning Regional Government, it is mentioned in detail about the domain of the authority of education management in Indonesia. The provincial government which has a new authority in secondary education management which was previously only authorized to coordinate became the center of attention for the academic community in viewing or analyzing the granting of such authority.

Politically, there is a uniform management of education policies. This is a concrete manifestation of material territorial or political decentralization. A material political decentralization is the transfer of a detailed or clear authority of its duties and functions. Therefore, the management of secondary education in Indonesia from the perspective of political decentralization for now is in accordance with or meets the criteria of political decentralization. When looking at the distribution of concurrent affairs in the field of education especially secondary education in the latest local government law, the authors provide an analysis that the management of secondary education by the provincial government makes territorial or political decentralization unmeet. In essence, the territorial decentralization in the field of education is the closest to the community and it is in accordance with the terminology of decentralization itself, releasing from the center and not recentralizing from what has been released.

\section{Conclusion}

Classification of decentralization in Indonesia is divided into 3 (three) parts, namely formal, material and real decentralizations. Then, the form of decentralization of education management in Indonesia uses territorial decentralization, considers the geographical conditions of Indonesia so that it is a consideration that Indonesia uses territorial decentralization in conducting concurrent government affairs, one of which is secondary education. Indonesia should not only use a form of territorial decentralization in government affairs, but also must use a form of cultural decentralization because Indonesia is a country that with diverse culture. Therefore, it needs to be preserved through a form of cultural decentralization.

\section{References}

Balkar, B., \& Kasurka, M. G. (2015). Decentralization as an Educational Planning Strategy in Turkish Education System. International Journal of Education, 7(2), 415-436.

Cohen, D. K., \& Ball, D. L. (1990). Relations between policy and practice: A commentary. Educational Evaluation and Policy Analysis, 12, 331-338.

Juwana, H. (2006). Legal education reform in Indonesia. Asian Journal of Comparative Law, 1(1), 1932-0205.

Koesoemahatmadja. (1979). Pengantar Kearah Sistem Pemerintahan Daerah Di Indonesia. Binacipta: Bandung. 
Limpo, I.Y., Bachri, S., Ilmar, A., and Patittingi, F. (2018), Potret of Basic Education in Indonesia (A Legal Political Study), Journal of Law, Policy and Globalization, Vol 69.

Manan, B. (1994). Hubungan Antara Pusat dan Daerah Menurut UUD 1945. Jakarta: Pustaka Sinar Harapan.

Muslimin. A. (1978). Aspek-Aspek Hukum Otonomi Daerah. Bandung: Alumni.

Poerbakawatja. (1970). Pendidikan Dalam Alam Indonesia. Jakarta: Gunung Agung.

The Liang Gie, (1968). Pertumbuhan Pemerintahan Daerah Di Negara Republik Indonesia, $3^{\text {rd }}$ edition. Jakarta: Gunung Agung.

Theo A.J. Toonen. (1987). Denken Over Binnenlands Bestuur Theorieen van de gedecentraliseerde eenheidstaat bestuurkundig beschouwd. Vuga, s'gravenhage. 